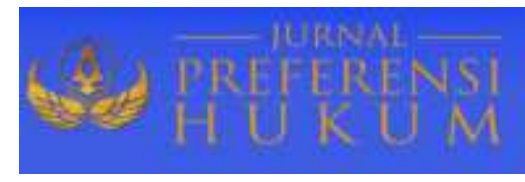

Jurnal Preferensi Hukum | ISSN: 2746-5039

Vol. 2, No. 2 - Juli 2021, Hal. 288-293| Available online at https://www.ejournal.warmadewa.ac.id/index.php/juprehum

DOI: https://doi.org/10.22225/jph.2.2.3324.288-293

\title{
PERLINDUNGAN HUKUM TERHADAP KONSUMEN MELALUI SERTIFIKASI HALAL PADA PRODUK OBAT-OBATAN BERDASARKAN UNDANG-UNDANG NO 33 TAHUN 2014 TENTANG JAMINAN PRODUK HALAL
}

\author{
Isye Aprilia, Ni Luh Made Mahendrawati, Ni Made Jaya Senastri \\ Fakultas Hukum, Universitas Warmadewa, Denpasar-Bali, Indonesia \\ isyeaprilia6@gmail.com, made.mahendrawati@gmail.com, nimadejayasenastri@gmail.com
}

\begin{abstract}
Abstrak
Obat-obatan harus mempunyai sertifikasi halal untuk menjamin kehalalan produk tersebut. Dalarn pasal 4 Undang-Undang Jaminan Produk Halal, mengatur bahwa semua produk yang beredar di Indonesia wajib bersertifikasi halal. Dalam kenyataannya banyak produk obat-obatan yang sudah beredar di masyarakat tetapi belum memiliki sertifikat halal. Sehingga hal ini menimbulkan masalah hukum yang berkaitan dengan perlindungan konsumen. Tujuan penelitian ini untuk menungkap kewenangan lembaga terkait dalam sertifikasi halal pada produk obat-obatan yang beredar di Indonesia serta perlindungan hukum terhadap konsumen apabila suatu produk obat yang telah disebarluaskan terdapat label halal namun belum memiliki label halal. Penelitian ini menggunakan metode penelitian hukum normatif dengan pendekatan konseptual serta perundang-undangan. Sumber bahan hukum dalam penelitian ini adalah bahan bukum primer dan sekunder. Teknik pengumpulan bahan hukum yang dengan menganalisa dan mengutip perundang-undangan yang berlaku dari buku, literatur, dan sumber lainnya. Hasil penelitian menunjukkan bahwa dengan dibentuknya Sadan Penyelenggara Jaminan Produk Halal, maka regulasi halal obat yang beredar di Indonesia tunduk pada Undang-Undang Jaminan Produk Halal No. 33 Tahun 2014 yang mengatur bahwa sertifikasi dan labelisasi produk halal bersifat wajib. Jika pelaku usaha melanggar kewajibannya berdasarkan peraturan tersebut, maka akan dikenakan sanksi administratif berupa teguran tertulis, denda administratif, penangguhan sertifikasi halal.
\end{abstract}

Kata Kunci: Obat-obatan, Perlindungan Hukum, Sertifikasi Halal.

\begin{abstract}
Medicines must have halal certification to ensure the halalness of the product. Article 4 of the Law on Halal Product Guarantee, stipulates that all products circulating in Indonesia must be certified halal. In fact, many medicinal products are already circulating in the community but do not yet have a halal certificate. So this raises legal problems related to consumer protection. The purpose of this research is to reveal the authority of related institutions in halal certification of medicinal products circulating in Indonesia as well as legal protection for consumers if a medicinal product that has been disseminated has a halal label even though it does not have a halal label. This study uses a normative legal research method with a conceptual approach and legislation. The source of legal material in this study is the primary and secondary legal materials. The technique of collecting legal materials by analyzing and quoting applicable laws from books, literature, and other sources. The results showed that with the establishment of the Halal Product Guarantee Organizer, the halal regulation of drugs circulating in Indonesia is subject to the Halal Product Guarantee Law No. 33 of 2014 which regulates that certification and labeling of halal products is mandatory. If business actors violate their obligations under these regulations, they will be subject to administrative sanctions in the form of written warnings, administrative fines, and suspension of halal certification.
\end{abstract}

Keywords: Medicine, Legal Protection, Halal Certification.

\section{PENDAhuluan}

Tidak adanya kesadaran konsumen beragama muslim saat memilih produk yang digunakannya, apakah itu halal ataupun tidaknya, membuat pelaku bisnis semena-mena akan produk yang dibuatnya. Kehalalan pun dijadikan suatu yang tidak harus padahal kepuasan batin konsumen muslim sebenarnya juga harus diperhatikan. Konsumen beragama Islam seharusnya mendapatkan perhatian dan juga penanganan dari pemerintah terkait mengenai suatu produk obat berkaitan dengan kehalalannya. Maka dari itu, pemerintah mengesahkan UUJPH yakni ada di UU No.33/2014, diperuntukkan kepada semua produk khususnya obat untuk wajib bersertifikasi halal. 
Sertifikasi dan pelabelan halal adalah dua aktivitas yang berbeda, tetapi keduanya terkait erat. Untuk menjamin perlindungan konsumen dari orang-orang yang beragama Islam, seluruh obat-obatan diharuskan bersertifikasi halal. Karena mengkonsumsi makanan yang halal merupakan kewajiban bagi setiap orang muslim. Sebagaimana yang dimaksud dalam firman Allah QS. Surah AI-Baqorah/2168 yang secara ringkas artinya bahwa Allah (Tuhan) mengajak seluruh umat manusia untuk memakan makanan halal dan baik yang ditemukan di bumi ini, ridak memperbolehkan urnat Islam untuk mengikuti Langkah setan (yang memakan makanan haram) karena setan adalah musuh yang nyata bagi seluruh umat yang beriman.

Menurut surat Al-Baqorah itu, Allah memerintah kan kepada semua umatnya untuk menyantap makanan yang halal dan mengharamkan, darah, daging babi, bangkai, dan binatang yang disembelih tanpa melafazkan nama Allah, terkecuali jika umatnya terdesak dan tak melebihi batasnya. Untuk bisa memastikan kehalalan suatu produk, produk tersebut harus berlabel halal dan bersertifikasi halal (Zulham, 2013). Di Negara Indonesia ini lembaga yang secara intens serta otoritas melakukan uji coba sertifikasi halal adalah Badan Penyelenggara Jaminan Produk Halal (yang selanjutnya disebut BPJPH). BPJPH merupakan perwujudan dari UU No. 33/2014. Penyelenggara sertifikasi halal dewasa ini dialihkan dari yang mulanya dilaksanakan oleh Mill yang di bagian ini adalah Lembaga yang mengkaji Pangan, Obat dan juga kosmetika MUI (LPPOM-MUI), sekarang ini diselenggarakan melalui BPJPH yang dinaungi oleh Kementrian Agama.

Sertifikasi halal oleh BPJPH ini sifatnya wajib (mandatory) namunmembuat para produsen obat enggan dan malas untuk meminta label halal kepada Lembaga tersebut pada produk yang diproduksinya sehingga cap halal sering kali diabaikan. Namun yang sebenarnya mengkonsumsi atau meminum produk obat-obatan yang didalamnya terkandung unsur tidak halal diperbolehkan/disahkan baik dari segi agama apabila dalam hal darurat, walaupun dalam kenyataannya masih minim produk obat-obatan yang merniliki sertifikasi halal tersebut dan enggan melakukan pelabelan halal pada kemasan obat-obatan yang dimilikinya.

Minimnya kualitas dari produk obat halal bisa meminimalisir pula tingkat keinsafan konsumen yang beragama Islam mengenai betapa pentingnya produk yang bersertifikasi halal dan hak dari konsumen itu tidak menjadi perhatian yang utama, maka dalam Pasal 4 (empat) huruf C UUPK mengatur bahwa konsumen berhak mendapatkan pemberitahuan yang benar, dimengerti dan terbuka tentang kondisi dan jaminan dari barang dan/atau jasa itu sendiri.

Dari segi konsumen Adapun beberapa peranan penting dari sertifikasi halal untuk sebuah produk yaitu

1. Terlindunginya seluruh konsumen yang beragama Islam dari seluruh produk obat yang notabenenya tidak halal

2. Dapat menegakkan jiwa dan raga dari keterpurukan setelah mengkonsumsi obat yang tidak halal

3. Menenangkan secara kerohanian dan kebatinan konsumen muslim

4. Adanya kepastian serta perlindungan hukum yangjelas kepada konsumen.

Selain hal tersebut yang dari sisi konsumen, dapat dilihat pula dari segi produsen labelisasi halal serta sertifikasinya memiliki peranan penting yang tidak kalah penting yakni

1. Meningkatkan prinsip halal yang merupakan bagian yang penting dari segi pertanggungjawaban untuk konsumen muslim

2. Meningkatkan kepastian serta kepuasan konsumen

3. Sebagai alat pemasaran dan perluasan pemasaran

4. Untuk memberikan peningkatan terhadap citra perusahaan serta persaingan antar perusahaan (Majelis Ulama Indonesia dan dan LPPOM M Ul, 2004:43).

Sertifikat halal merupakan fatwa yang disetujui oleh MUI yang menyatakan kehalalan suatu produk sesuai dengan hukum Islam. Sertifikat Halal ini merupakan syarat untuk mencantumkan label halal pada produk yang memenuhi syarat kehalalan berdasarkan hukum Islam (Triasih et al., 2016). Lebih lanjut, menurut (Rahmah \& Barizah, 2020) berpendapat bahwa Label halal yang ada pada obatobatan meyakinkan konsumen khususnya muslim bahwa obat tersebut diproduksi sesuai hukum Islam. Dapat dikatakan sebagai obat halal jika sudah disiapkan, diproses, diproduksi atau disimpan menggunakan instrumen atau ramuan yang diperbolehkan oleh Hukum Islam. Salah satu fokus sertifikasi halal di Indonesia yaitu farmasi industri, makanan, kosmetik. Hal tersebut mencerminkan UUJPH pasal 1 angka 1 yang menyatakan bahwa produk yang dimaksud dalam undang-undang ini meliputi barang atau jasa yang berkaitan dengan makanan, minuman, obat-obatan, kosmetik, produk 
kimia, produk biologi, rekayasa genetika produk, dan barang bekas atau dimanfaatkan oleh masyarakat (Ridwan et al., 2020). Dengan hal tersebut bisa disimpulkan bahwasanya adanya sertifikasi halal ini dapat memberikan jaminan kepada masyarakat muslim di Indonesia untuk proteksi kenyamanan serta keamanan dalam penggunaan obat-obatan karena selain dari segi farmasi dan bahan dasarnya juga tidak bertentangan secara hukum nasional yang berlaku, hukum agama Islam serta memberikan kesadaran untuk penggunaan produk halal bagi masyarakat muslim.

Maka berdasarkan uraian diatas, tujuan dari penelitian ini untuk menganalisa kewenangan lembaga terkait dalam sertifikasi halal pada produk obat-obatan yang beredar di Indonesia serta perlindungan hukum terhadap konsumen apabila suatu produk obat yang telah disebarluaskan terdapat label halal namun belum memiliki label halal.

\section{METODE PENELITIAN}

Tipe penelitian yang diaplikasikan adalah penelitian hukum secara normatif, yang dimana meletakkan hukum sebagai suatu sistem norma yang diberlakukan. Tipe ini diterapkan untuk penerapan kaidah norma yang berlaku didalam hukum positif Indonesia yang berdiri diatas doktrin bahwa hukum identik dengan norma murni dalam arti obyektif bebas dari nilai ideologis, etis, sosiologis (Atmadja, I Dewa Gede Budiartha, 2018). Penelitian ini dibuat dengan menganalisis hukum yang sifatnya formal dengan sumber hukum primer dan sekunder, contohnya seperti Undang-undang dan seluruh peraturan secara hirarki, dan buku-buku yang memuat norma atau konsep teoritis dan juga pendapat dari para sarjana. Pendekatan masalah yang digunakan yakni pendekatan konseptual serta perundang-undangan, dimana pendekatan konseptual yakni seperti pendapat para sarjana secara teoritis, sedangkan pendekatan perundang-undangan adalah aturan tertulis yang dibuat oleh pejabat yang berwenang, dibentuk secara umum serta disahkan oleh Negara (Marzuki, 2014). Teknik pengumpulan bahan hukum yang dengan menganalisa dan mengutip perundang-undangan yang berlaku dari buku, literatur, dan sumber lainnya. Data yang telah diperoleh kemudian dianalisis dan disajikan secara deskriptif.

\section{HASIL DAN PEMBAHASAN}

1. Kewenangan Lembaga Terkait dalam Sertifikasi Halal pada Produk Obat-obatan yang Beredar di Indonesia

Sertifikasi dilakukan dengan melakukan serangkaian pemeriksaan oleh auditor untuk kemudian ditetapkan status kehalalannya sehingga tercipta suatu fatwa tertulis yang menyatakan kehalalan produk dalam bentuk sertifikat halal (Hasan, 2014). Lebih lanjut, menurut (Faridah, 2019). Sertifikat halal berlaku selama kurun waktu empat tahun yang emudian bisa dilakukan perpanjangan. Perusahaan harus memberikan jaminan halal dengan selalu menjaga konsistensi kehalalan produk. Secara berkala setiap enam bulan sekali harus melaporkan pelaksanaan Sistem Jaminan Halal (SJH) pada perusahaannya

Beberapa faktor pentingnya UUJHP antara lain menurut (Mashudi, 2011).

1. Tidak adanya kepastian hukum yang jelas structural pemerintahan mana yang secara gambling mengatur mengenai keterlibatannya dalam jaminan produk halal. Dewasa ini masyarakat muslim khususnya belum diberikan kepastian secara jelas mengenai wewenang. Tugas dan juga fungsi mengenai terdapatnya jaminan produk yang bersertifikasi halal termasuk alur koordinasinya. Fatwa MUI masih meragukan legal standingnya dan sistem sekarang ini belum memastikan bagaimana fatwa MUI dijadikan sebagai hukum nasional dan instrumen hukum nasional (Sholeh, 2018).

2. Seluruh peraturan tertulis yang ada belum memberikan kepastian mengenai produk halal artinya bahwa kepastian hukumnya pun belum jelas. Menimbulkan adanya keraguan secara lahir dan batin karena konsumen tidak bisa membedakan antara barang halal dan haram. Aturan halal tersebut juga seharusnya mengatur diluar obat-obatan saja, namun juga rnakanan, minuman, rekayasa genetik, produk kirnia biologis.

3. Produk yang beredar di pasaran semakin tidak terkontrol disebabkan meningkatnya teknologi, proses kimia biologis, rekayasa genetik dan biogenetic.

Karakter yang sangat menonjol dalam UUJPH adalah sifatnya yang disebut mandatory atau diwajibkan, hal ini bisa dilihat dari Pasal 4 UUJPH diringkas menyatakan segala jenis-jenis produknya yang tersebar secara luas di wilayah Indonesia diharuskan untuk bersertifikasi halal. 
Dengan hal tersebut bisa dipahami pengaturan labelisasi dan sertifikasi adalah wajib atau mandatory, Apabila dalam berjalannya suatu bisnis yang bersangkutan atau pengusaha melanggar aturan UUJPH maka pelaku akan dikenakan sanksi administratif yang telah diatur dari Pasal 27 UUJPH yaitu

1. Diberikannya peringatan secara tertulis

2. Dikenakan denda administratif

3.Yang terakhir akan dilakukan pencabutan sertifikasi halal

Saat ini dunia obat-obatan dan kosmetik berkernbang sangat pesat karena ragam penyakit pun semakin pesat juga perkembangnya, terlebih saat terdampak wabah Pandemi Covid-19. Aspek halal seringkali diabaikan oleh orang yang memproduksi di bidang farmasi karena menggunakan bahan yang asalnya merupakan tubuh manusia, babi dan bahan yang haram lainnya yang tidak diperbolehkan. Seringkali ditemukan pada obat-obatan adanya campuran babi, yakni pada bahan yang utama, penolong dan bahkan tambahan. Sering didapati pula organ manusia berupa ernbrio, dan penggunaan alkohol. Ditemukan juga obat mengandung unsur daging babi seperti Insulin yakni hormon yang berfungsi mengontrol gula di dalam organ manusia yang dapat mengobati diabetes. Penderita diabetes perlu menyerap hormon dari tubuh untuk menetralkan dan menormalkan kandungan gula dalam tubuh. Insulin ini dirnasukkan ke tubuh manusia melalui injection. Insulin yakni asalnya dari suatu kelenjar makhluk hidup jenis mamalia dan/ atau seperti mikroorganisme kelenjar mamalia

Apabila berasal dari mamalia, insulin yang menyerupai dengan manusia ialah yang berasal dari hewan yaitu babi dengan rincian sebagai berikut

Insulin manusia yaitu C256H38 I N65076S6 MW= 5807,7

Insulin sapi yaitu C254H377N65075S6 MW= 5733,6 (3 asam amino berbeda)

Dan insulin babi C257H383N65077S6 MW= 5777,6 (hanya I Asam Amino yang membedakan)

Salah satunya produknya yang ada di pasaran yaitu produk Mixtard berasal oleh Novo Nordisk. Terdapat beberapa jenis mixtard juga dibuat dengan kode produksi yang berbeda. Kandungannya berbeda juga, ada yang berusul dari badan orang dan di replikasi melalui teknologi rekombinasi DNA dan serta proses mikrobaan, dan terdapat juga berasal tubuh hewan atau khususnya babi. Info halalnya suatu produk sangatlah minim bahkan orang-orang yang bertugas di dunia Kesehatan tidak semua mengetahuinya. Berasal dari data yang diupload oleh International Diabetes Federation Pada di tahun 2003 menyatakan, ada 70\% insulin yang beredar dan asalnya dari manusia, $17 \%$ dari hewan yakni babi, $8 \%$ dari hewan sapi, dan 5\% berasal dari campuran daging sapi dan babi. Fatwa MUI mengenai Obat serta Pengobatan Nomor 30 Tahun 2013 menyatakan bahwa

1. Islam menyarankan (mensyariatkan) pengobatan yakni bagian dari menjaga Al-Dharuriyat Al-Kham.

2. Hams tetap melakukan pengobatan yang notabennya tentu tidak melenceng dari ajaran dalam suatu ikhtiar penyembuhan penyakit didalam tubuh manusia.

3. Obat yang dikonsumsi wajib dari bahan yang tidak mengandung najis dan halal

4. Haram hukumnya menggunakan obat yang berbahan diluar daripada syariat Islam

5. Obat yang mengandung najis dan haram dapat digunakan dengan memenuhi syariat

a. Tidak adanya bahan yang halal

b. Dalam kondisi terpaksa (al-dlarura), yakni apabila tidak digunakan mengancam jiwa, atau juga kondisi terdesak (al-hajat allati tamilu manzllab al-dlarurat) apabila tidak digunakan akan mengancam jiwa manusia di kemudian hari

c. Adanya rekomendasi dari pihak yang berwajib bahwa untuk obat yang halal tidak ada digunakan

6. Obat yang berbahan haram atau najis boleh digunakan untuk pengobatan luar dengan dilakukan pensucian menurut ajaran Islam. Tata cara prosedur pengajuan sertifikasi halal oleh BPJ PH, yaitu

a. Permohonan Sertifikasi Halal diajukan oleh Pelaku Usaha dengan melampirkan dokumen berupa nama dan jenis produk, data dari pelaku usaha, daftar produk serta bahan-bahan yang digunakan dalam mengolah produk.

b. Meminta untuk dilakukan pemeriksaan kehalalan produk oleh Lembaga auditor halal

c. Dilakukan pengauditan di pabrik tempat pembuatan produk, apabila meragukan akan dilakukan pengujian laboratorium

d. LPH mengajukan hasil audit ke BPJPH 
e. BPJPH mengajukan kehalalan produk ke MUI untuk penerbitan sertifikasi halal

f. Penetapan kehalalan dilakukan MUI, dilakukan siding Fatwa Halal yang mengikutsertakan pakar halal, Lembaga pemerintahan dan instansi terkait. Sidang tersebut paling lama 30 hari kerja sejak dari MUI menerima hasil audit. Keputusan halal di tandatangani oleh MUI dan disampaikan kepada BPJPH sebagai dasar penerbitan sertifikat.

g. BPJPH menerbitkan sertifikat halal, apabila produk dinyatakan tidak halal BPJPH mengembalikan permohonan sertifikat disertai dengan alasan kepada yang mengajukan (pengusaha). Sertifikat paling lama diterbitkan 7 hari terhitung saat keputusan kehalalan produk diterima dari MUT.

\section{Perlindungan Hukum Terhadap Konsumen Apabila Suatu Produk Obat yang Telah disebarluaskan Terdapat Label Halal Namun Belum Memiliki Label Halal.}

Konsumen berhak untuk memperoleh jarninan perlindungan hukum dari Undang-undang Perlindungan Konsumen, Berdasarkan pasal 4 UUPK tentang hak-hak konsumen yakni

1. Konsumen berhak atas rasa nyaman, aman dan kesejahteraan dalam mengkonsumsi barang dan/atau jasa

2. Konsumen berhak untuk memperoleh barang dan/jasa berdasarkan kondisi, nilai tukar dan jaminan yang dijanjikan

3. Konsumen berhak atas informasi yang jelas, akurat dan jujur menangani barang dan/atau jasa

4. Berhak untuk mengajukan keberatannya atas barang dan/atau jasa yang digunakannya

5. Konsumen berhak untuk mendapatkan pernbelaan, pengamanan dan upaya penyelesaian sengketa sebagaimana mestinya

6. Konsumen berhak atas pembinaan dan edukasi konsumen

7. Konsumen berhak untuk dijamu dan diperlakukan dengan baik serta tanpa adanya diskriminasi

8. Berhak untuk menerima ganti rugi dan/atau penggantian, berupa kompensasi apabila barang dan/atau jasa yang diterima tidak sesuai dengan kesepakatan atau tidak sesuai syarat yang semestinya

9. Hak yang diberikan oleh hukum dan lainnya.

Pada Pasal 5 UUPK juga mengatur tentang kewajiban dari konsumen yakni

1. Mengikuti perunjuk dengan melihat informasi dan aruran tata cara pemakaian, pemanfaatan barang dan/atau jaga untuk menciptakan keselarnatan dan keamanan

2. Memiliki itikad baik untuk melaksanakan kesepakatan pembelian barang dan/atau jasa

3. Melunasi setara dengan nominal yang diperjanjikan.

Dengan dilakukannya labelisasi halal terhadap kemasan pada suatu produk obat wajib untuk dicantumkan yang menerangkan apabila produk yang siap dikonsumsi masyarakat telah menerima sertifikat halal dari MUI dan benar dinyatakan halal. Jika ada produk yang tidak halal maka akan dilakukan uji laboratorium untuk diperiksa kembali dan diuji lagi agar tidak terkandung barang subhat atau meragukan. Selain ha! tersebut apabila terdapat produk yang belum biasa dikatakan halal serta tidak ada label halal yang sebenarnya maka produk tersebut harus mencanrumkan di dalam kemasannya bahwa produk itu memang benar tidak halal karena bersinggungan dengan bahan yang tidak dihalalkan secara syariat Islam.

Peredaran obat halal yang tidak bersertifikat halal merupakan penipuan atau pemalsuan label halal pada kemasan farmasi, kemudian ditarik dari peredaran. Sebelum produknya ditarik dari peredaran, perusahaan akan dikenakan sanksi hingga 3 (tiga) kali. Jika perusahaan tidak ingin mendaftarkan produknya dan tetap mencantumkan label halal pada kemasannya, maka BPJPH terpaksa mengambil tindakan tegas yaitu mencabut sertifikasi halal.

\section{SIMPULAN DAN SARAN}

\section{Simpulan}

Berdasarkan hal yang telah diuraikan, maka penulis dapat menarik simpulan dan menjadi jawaban dari rumusan masalh diatas yakni Pengaturan mengenai label atau sertifikat halal pada sebuah produk obat yang tersebar di Indonesia diatur dalam UUJPH dengan dibentuknya BPJPH, dalam peraturan tersebut sertifikasi dan labelisasi produk halal bersifat wajib atau yang disebut mandatory dimana 
sebelumnya bersifat sukarela atau yang disebut voluntary, BPJPH mempunyai kekuasaan membuat keputusan unruk menerbitkan dan menanggalkan sertifikasi halal dan label halal yang dimiliki oleh suatu produk. Selain UUJPH ada pengaruran lain yang juga mengarur mengenai sertifikasi halal pada produk obat-obatan yaitu Peraturan Kepala Badan Pengawas Obat dan Makanan Republik Indonesia Nomor HK.03.1.23.06.10.5166 Tentang Pencanruman lnformasi Asal Bahan Tertentu, Batas Kadaluarsa, dan Kandungan Alkohol pada Penandaan I Label Obat, Obat Tradisional, dan juga Suplemen Makanan dan Pangan, UUPK Pasal 8 ayat (1) huruf H, dan Fatwa MUI No.30 (tiga puluh) tahun 2013 tentang Obat dan Pengobatan. Adapun bentuk perlindungan hukumnya yang diperoleh kepada konsumen apabila terdapat produk obat yang memberikan label/tanda halal pada kemasannya padahal dalam kenyataannya belum memiliki sertifikat halal akan diberlakukan sanksi administratif bagi pelaku usaha tersebut berupa yang pertama peringatan terrulis, yang kedua akan dikenakan denda administratif, dan yang terakhir akan dilakukan pencabutan sertifikasi halal, dan juga ada sanksi pidana yang diarur dan dimuat di dalam UUJPH. Untuk meminimalisir beredamya produk obatobatan yang mencantumkan logo halal padahal tidak bersertifikasi halal yakni dengan mengoptimalkan cara dan mekanisme dari pemeriksaan sesuai norma yang diberlakukan, sehingga norma tersebut yang diberlakukan oleh pemerintah mampu berjalan dengan baik di masyarakat. Pengawasan pada suatu produksi serta pengedaran obat yang bersertifikasi halal, di bagi menjadi dua pengawasan yakni pengawasan yang dilakukan oleh BPOM dan yang kedua dilakukan oleh BPJPH.

\section{Saran}

Pelaku usaha wajib mengikuti aturan yang telah ditentukan dan mengupayakan adanya sertifikat halal dalam produk yang diperjual belikannya baik lokal maupun import agar dapat memberikan kepastian hukum yang jelas kepada pihak konsumen yang mengkonsumsi. Peran pemerintah dalam rangka penggunaan label halal ini adalah menghimbau BPJPH dan masyarakat untuk bisa optimal dalarn hal pengawasan pada produk penggunaan obat dan makanan halal yang tersebar di pelosok negeri, agar dapat mewujudkan kenyamanan pada konsumen yang menerima produknya. Terciptanya penegakan pada bidang hukum yang jelas serta tepat pada peran melindungi hak konsumen. Masyarakat harus sadar pada produk obat yang akan diminumnya yang telah beredar. Terutama produk yang labelnya halal tapi tidak atas dasar hukum yang jelas. Hal ini bisa menghindari dampak kerugian immateriil pada konsumen muslim khususnya. Jika konsumen masih memiliki pertanyaaan mengenai kehalalan suatu obat, mereka dapat melihat obat bersertifikat halal di website MUI.

\section{DAFTAR PUSTAKA}

Atmadja, I Dewa Gede Budiartha, I. N. P. (2018). Teori-Teori Hukum. Setara Press, Malang.

Hasan, K. S. (2014). Kepastian Hukum Sertifikasi dan Labelisasi Halal Produk Pangan. Jurnal Dinamika Umum, 14(2), 227-238.

Faridah, H. D. (2019). Sertifikasi Halal di Indonesia: Sejarah, Perkembangan, dan Implementasi. Journal of Halal Product and Research, 2(2), 68-78.

Mashudi. (2011). Konstruksi Hukum \& Respons Masyarakat Terhadap Sertifikasi Produk Halal. Pustaka Pelajar, Yogyakarta.

Marzuki, P. M. (2014). Penelitian Hukum Edisi Revisi. Prenada Media Grup, Jakarta.

Rahmah, M., \& Barizah, N. (2020). Halal Certification of Patented Medicines in Indonesia in Digital Age: A Panacea for the Pain? Journal of Systematic Reviews in Pharmacy, 11(12), 210-217.

Ridwan, A. H., Hasanuddin, M., Fatahillah, I. A., \& Fauzia, I. (2020). Authorization of Halal Certification in Indonesia, Malaysia And Singapore. International Journal of Psychosocial Rehabilitation, 24(8), 7992-8011.

Sholeh, A. N. (2018). Jaminan Halal Pada Produk: Obat Kajian Fatwa MUI dan Penyerapannya Dalam UU Jaminan Prociuk Halal. Journal of Islamic Law Studies, 1(1), 70-87.

Triasih, D., Heryanti, B. R., \& Kridasaksana, D. (2016). Kajian tentang Perlindungan Hukum bagi Konsumen Terhadap Produk Makanan Bersertifikat Halal. Jurnal Dinamika Sosial Budaya, $18(2), 214-225$.

Zulham. (2013). Hukum Perlindungan Konsumen. Kencana Prenada Media Grup, Jakarta. 